\title{
Nutrition Modeling During the Prenatal Development of the Fetus
}

\section{Yakubov Maksadkhon Sultaniyazovich ${ }^{1}$, Shikhnazarova Guzal Alisherovna²}

Section: Healthcare

Sci. Journal Impact

Factor: 6.1 (2018)

ICV: 90.90 (2018)

c) (i) (8)

Copyright@IJCRR
'Sciences, Professor of Tashkent University of Information Technologies, Uzbekistan; ${ }^{2}$ Assistant at Tashkent University of Information Technology, Uzbekistan.

\section{ABSTRACT}

Introduction: The issues of modelling the process of determining the diet of pregnant women in three trimesters of fetal development are considered.

Aim: The analysis of the dynamics of the development of the fetus, taking into account the saturation of nutrients and vitamins in food. Scientific evidence of nutrigenomics indicates the effects of nutritional factors at the gene level.

Method: A successfully developing new scientific field, epigenomics, is studying the influence of various environmental factors, and above all nutrition, on the expression of maternal and fetal genes. The main types of nutrients in products that provide a rational diet for pregnant women have been identified. Even when using a diverse set of products in nutrition, the majority of women have found an insufficient supply of vitamins and minerals in various combinations.

Conclusion: The reason for this is a significant decrease in the content of vitamins and minerals in food, which is associated with the use of active, and sometimes aggressive agricultural technologies in agriculture.

Key Words: Modelling, Prenatal development of the fetus, Rational diet, Mathematical model, Differentiated dietetic nutrition.

\section{INTRODUCTION}

All environmental factors that affect human health, the leading role belongs to nutrition. It should not be forgotten that the smaller the child's age, the greater attention should be paid to nutrition. ${ }^{1}$

Numerous studies have shown that the health of a child is greatly influenced not only by the nutrition of a pregnant woman but also by the rational nutrition of the mother and father of the child even before conception. In this regard, a new direction has appeared in the organization of nutrition of the expectant mother - "pre-conceptual prevention", which provides for the proper nutrition of a woman before conception, which will prevent a deficiency of certain nutrients during pregnancy. ${ }^{2}$

Special epidemiological studies indicate that eating disorders during pregnancy can lead to serious consequences: miscarriage, premature birth, childbirth with various intrauterine defects, lag in physical and mental development. However, the not only deficiency is dangerous, but also excessive consumption of certain micronutrients, especially vitamin A, which is toxic in large doses. ${ }^{3}$

Moreover, the deficiency of certain macro- and micronutrients in the prenatal period affects not only the formation of the fetus but also negatively affects the future state of the child's health and is a risk factor for the development of several diseases in adulthood.

Diet is a specially selected diet in terms of quantity and quality of nutrients, as well as a diet to achieve certain goals (weight loss, weight gain, better health). The main thing in the preparation of dietary nutrition is the established scientifically based physiological norms of nutrition. Following them, a person's nutrition should satisfy his physiological needs for nutrients and energy. The main nutrients (proteins, fats, carbohydrates), as well as other necessary components (vitamins), must be ingested in the right amount following the needs of a particular person. The physiological needs for the amount and time of intake of the necessary

\section{Corresponding Author:}

Yakubov Maksadkhon Sultaniyazovich, Sciences, Professor of Tashkent University of Information Technologies, Uzbekistan; Email: maksadhan@mail.ru

ISSN: 2231-2196 (Print) ISSN: $0975-5241$ (Online)

Received: 10.07 .2020

Revised: 12.08 .2020

Accepted: 14.09 .2020

Published: 06.10 .2020 
nutrients depend on a large number of factors: gender, age, health, body weight, physical activity, etc. All these factors must be considered when creating the right diet. ${ }^{3,4,5}$

During prenatal development of the fetus, the diet of the pregnant woman is important. Depending on the physique, weight, health status, anaemic conditions, psychological state, the doctor prescribes a diet containing various types of vitamins. Each type of product should contain all the necessary nutrients for the body.

It is necessary to balance protein, essential amino acids, vitamins and minerals. The lack of trace elements and minerals in the diet (sodium, calcium, phosphorus, etc.) is compensated by the use of special additives. With a deficiency or excess of at least one element in the diet, the efficiency of the use of nutrients of the entire diet has deteriorated. ${ }^{6}$

In substantiating the principles of rational nutrition of pregnant women, two aspects of the problem should be kept in mind: on the one hand, the physiological needs of the fetus and newborn are met in essential nutrients and the energy necessary for its adequate growth and development, and on the other, the physiological needs of the pregnant woman are needed to preserve her health and performance, ensure comfortable health.

To compile a diet, you need to calculate a daily diet, i.e. the amount of each product $\mathrm{Pj}$, on the one hand, to provide the minimum required amount of nutrients, and on the other hand, to minimize the cost of the developed diet.

To facilitate the fulfilment of the above goals, a mathematical model of the diet problem is compiled. In general terms, this model is as follows. The mathematical model will take the form:

$$
\begin{aligned}
& F=c_{1} x_{1}+c_{2} x_{2}+\cdots+c_{n} x_{n} \rightarrow(\mathrm{min}) \\
& \left\{\begin{array}{c}
a_{11} x_{1}+a_{12} x_{2}+\cdots+a_{1 n} x_{n} \geq b_{1}, \\
a_{21} x_{1}+a_{22} x_{2}+\cdots+a_{2 n} x_{n} \geq b_{2}, \\
\cdots \\
a_{m 1} x_{1}+a_{m 2} x_{2}+\cdots+a_{m n} x_{n} \geq b_{m}, \\
x_{1} \geq 0, x_{2} \geq 0, \ldots, x_{n} \geq 0
\end{array}\right. \\
& F=\sum_{i=1}^{n} c_{i} x_{i} \rightarrow(\mathrm{min}) \\
& \left\{\begin{array}{c}
\sum_{i=1}^{n} a_{i j} x_{i} \geq b_{i}, i=1,2, \ldots, m, \\
x_{i} \geq 0, j=1,2, \ldots, n .
\end{array}\right.
\end{aligned}
$$

$x_{j}(j=1,2, \ldots, n)-$ the amount of $j$-th product in the daily diet. The diet uses $n$ types of products. Each product contains $\mathrm{m}$ necessary nutrients in an amount of at least bi $(i=1,2, \ldots$, m) units, aij is the number of units of the required nutrient Bi in a j product unit product. It is necessary to draw up a diet of the necessary nutrition at the minimum cost for it.

In the task of compiling a diet (diet, feed mixture), restrictions can be used not only on the required minimum of nec- essary substances but also on the minimum weight of the mixture.

To solve the problem, it is necessary to formulate its mathematical model, initially placing the source data in table 1 .

\section{Table 1: Content of essential substances in the prod-} uct

\begin{tabular}{lccccc}
$\begin{array}{l}\text { Essential } \\
\text { Substances }\end{array}$ & Minimum & \multicolumn{3}{c}{$\begin{array}{c}\text { Content of essential sub- } \\
\text { stances in the product }(\mathbf{j})\end{array}$} \\
& & $\mathrm{P}_{1}$ & $\mathrm{P}_{2}$ & $\ldots$ & $\mathrm{P}_{\mathrm{n}}$ \\
$\mathrm{B}_{1}$ & $\mathrm{~b}_{1}$ & $\mathrm{a}_{11}$ & $\mathrm{a}_{12}$ & $\ldots$ & $\mathrm{a}_{1 \mathrm{n}}$ \\
$\mathrm{B}_{2}$ & $\mathrm{~b}_{2}$ & $\mathrm{a}_{21}$ & $\mathrm{a}_{22}$ & $\ldots$ & $\mathrm{a}_{2 \mathrm{n}}$ \\
$\ldots$ & $\ldots$ & $\ldots$ & $\ldots$ & $\ldots$ & $\ldots$ \\
$\mathrm{B}_{\mathrm{m}}$ & $\mathrm{b}_{\mathrm{m}}$ & $\mathrm{a}_{\mathrm{m} 1}$ & $\mathrm{a}_{\mathrm{m} 2}$ & $\ldots$ & $\mathrm{a}_{\mathrm{mn}}$ \\
Product cost & & $\mathrm{c}_{1}$ & $\mathrm{c}_{2}$ & $\ldots$ & $\mathrm{c}_{\mathrm{n}}$ \\
\hline
\end{tabular}

For example, a pregnant woman can purchase $n$ types of raw materials and prepare various types of mixtures. Each raw material contains a different amount of the necessary substances for the mixture. The mixture should meet the minimum utility requirements. It is necessary to determine the amount of each $\mathrm{j}$-th type of raw material, forming a mixture of minimum cost, subject to the requirements for the total consumption of the mixture and its nutritional value. The optimization problem based on a mathematical model will have the form ${ }^{2-5}$

$F=\sum_{i=1}^{n} c_{i} x_{i} \rightarrow(\min )$,

\section{under restrictions:}

- total consumption of the mixture: $\sum_{i=1}^{n} x_{i}=q$;

- nutritional value of the mixture:

$$
\begin{aligned}
& \sum_{i=1}^{n} a_{i j} x_{i} \geq b_{i} \sum_{i=1}^{n} x_{i}, i=1,2, \ldots, m, \\
& \text { - } \quad x_{j} \geq 0, j=1,2, \ldots, n ;
\end{aligned}
$$

where: $x j$ is the amount of $\mathrm{j}$-th raw material in the mixture; $\mathrm{n}$ is the number of types of raw materials; $\mathrm{m}$ is the amount of nutrients;

aij is the amount of the i-th nutrient contained in the unit of the $\mathrm{j}$-th type of raw material;

$\mathrm{b}_{1}-$ the minimum amount of the $\mathrm{i}$-th nutrient contained in the unit of the mixture;

$c_{j}$ - unit cost of raw material $j$;

$q$ - minimal general view of the mixture.

Vitamins have extremely high biological activity and are required by the body in very small quantities (from a few micrograms to tens of $\mathrm{mg}$ ), i.e. are minor components of food (micronutrients). Unlike other essential nutrients (essential amino acids, polyunsaturated fatty acids), vitamins are not a 
building material or energy source and participate in metabolism mainly as biocatalysts and regulators. The human need for vitamins (physiological need) is an objective value that has developed during evolution and does not depend on our knowledge. Based on scientific data on the study of physiological needs, the recommended intake rate (RNP) of vitamins is established (Table 2). It fully covers the need of any person. The need and, accordingly, RNP for pregnant women is approximately $25 \%$ higher than for women of childbearing age.

Table 2: Vitamins in foods

\begin{tabular}{|c|c|c|c|}
\hline Vitamin & Women & $\begin{array}{l}\text { Pregnant } \\
\text { women }\end{array}$ & $\begin{array}{l}\text { Vitamins in foods ( } \mathrm{mg} / \\
\text { loog) }\end{array}$ \\
\hline С, мг & $70-80$ & $90-100$ & $\begin{array}{l}\text { Rosehip (426), green pep- } \\
\text { per (127), parsley (133), } \\
\text { kiwi (92), broccoli (89), } \\
\text { dill (85), strawberries (59), } \\
\text { orange (53), lemon (53), } \\
\text { pineapple (47) }\end{array}$ \\
\hline A, мг & $0,8-1,0$ & $1,0-1,2$ & $\begin{array}{l}\text { Beef liver (5), cream (o.4), } \\
\text { spinach (o.45), carrots } \\
\text { (o.8), butter (o.6), parsley } \\
(0.4) \text {, cilantro (o.3), apricot } \\
(0,1) \text {, fish oil (30) }\end{array}$ \\
\hline $\mathrm{E}, \mathrm{mg}$ & 8 & 10 & $\begin{array}{l}\text { Oil ( } 41) \text {, seeds }(35) \text {, al- } \\
\text { monds }(25) \text {, dried apricots } \\
(4.3) \text {, olives }(3.8) \text {, turnips } \\
(2.8) \text {, peanuts }(8.3)\end{array}$ \\
\hline $\mathrm{D}, \mathrm{ME}$ & 100 & 500 & $\begin{array}{l}\text { (IU / 10og) fish oil (10ooo), } \\
\text { mackerel (643), egg yolk } \\
\text { (218), beef liver (49), salm- } \\
\text { on (441), whole milk (2) }\end{array}$ \\
\hline $\mathrm{B} 1, \mathrm{mg}$ & $1,1-1,5$ & $1,5^{-1,9}$ & $\begin{array}{l}\text { Pine nuts (34), beef liver } \\
\text { (o.3), buckwheat (o.3), } \\
\text { pistachios (1), wheat (o.4), } \\
\text { walnut (0.4), oatmeal (0.4), } \\
\text { corn ( } 0.4) \text { pasta (0.25) }\end{array}$ \\
\hline
\end{tabular}

\begin{tabular}{|c|c|c|c|}
\hline $\mathrm{B} 2, \mathrm{mg}$ & $1,3-1,8$ & $1,6-2,1$ & $\begin{array}{l}\text { Pine nuts (88), liver (2.2), } \\
\text { chicken egg (0.4), porcini } \\
\text { mushroom (o.3), cottage } \\
\text { cheese (o.3), rose hip (o.3), } \\
\text { spinach (0.25), processed } \\
\text { cheese (0.4), goose (o.23), }\end{array}$ \\
\hline B6, mg & 1,8 & 2,1 & $\begin{array}{l}\text { Pine nuts (124), beans } \\
\text { (o.9), walnuts (o.8), sea } \\
\text { buckthorn (o.8), garlic } \\
\text { (o.6), pomegranate (o.5), } \\
\text { millet (o.5), pepper (o.5), } \\
\text { chicken (0.5), beef liver } \\
\text { (o.7) }\end{array}$ \\
\hline PP, mg & $14-20$ & $16-22$ & $\begin{array}{l}\text { Peanuts (19), pine nuts } \\
(8) \text {, turkey (13), beef ( } 8) \text {, } \\
\text { chicken (12), rabbit (12), } \\
\text { wheat ( } 7) \text {, goose ( } 8.6) \text {, } \\
\text { mackerel (11), salmon ( } 9) \text {, } \\
\text { liver (17), peas ( } 6.5)\end{array}$ \\
\hline
\end{tabular}

Table 2: (Continued)

\begin{tabular}{|c|c|c|c|}
\hline Vitamin & Women & $\begin{array}{l}\text { Pregnant } \\
\text { women }\end{array}$ & $\begin{array}{l}\text { Vitamins in foods ( } \mathrm{mg} / \\
\text { loog) }\end{array}$ \\
\hline $\begin{array}{l}\text { Folic } \\
\text { Acid, mcg }\end{array}$ & 200 & 400 & $\begin{array}{l}\text { (mcg / 10og) Peanuts (240), } \\
\text { beef liver }(240) \text {, beans } \\
(90) \text {, lettuce }(48) \text {, spinach } \\
\text { (8o), broccoli }(63) \text {, porcini } \\
\text { mushroom (40), leek (32) }\end{array}$ \\
\hline $\mathrm{B} 12, \mathrm{mkg}$ & 3,0 & 4,0 & $\begin{array}{l}\text { (mcg / 10og) Beef liver ( } 83) \text {, } \\
\text { rabbit (7), Swiss cheese ( } 3) \text {, } \\
\text { lamb (2.3), beef (1.9), cow's } \\
\text { milk (o.5), chicken breast } \\
(0.34)\end{array}$ \\
\hline
\end{tabular}

In the first half of pregnancy, when the fetus is still small, and the woman continues to lead a normal lifestyle, the need for basic nutrients and energy remains practically unchanged and corresponds to physiological norms. It is important that the food is as diverse as possible and includes all groups of products. Particular attention should be paid to sufficient content in the diet of fresh vegetables, fruits, berries, greens, which are full sources of vitamins and minerals. The results of numerous and repeated studies of the diets of pregnant women in the Republic indicate the insufficient use of this particular group of products. ${ }^{6,7}$

An important condition for the proper nutrition of a woman during pregnancy, especially in the second half, is the gentle heat treatment of products. It should be consumed mainly boiled and stewed, and not fried meat, fish, vegetables.

It should be borne in mind that in the second half of pregnancy, the liver and kidneys experience increased loads, as they carry out the processes of detoxification and excretion of the final metabolic products of not only their body, but also the fetus, so a limited intake of salt, salty foods, and liquid are recommended.

\section{CONLCUSION}

One of the criteria for the proper selection of food products for pregnant women is an increase in body weight, which in the second half of pregnancy should not exceed $300 \mathrm{~g}$ per week, and for the entire period of prenatal development of the fetus, a woman gains about - $10-12 \mathrm{~kg}$.

Unfortunately, it is not always possible to provide pregnant women rations with a whole set of natural products. This is due to insufficient attention of women to their diet or misconceptions about the benefits or dangers of certain products. 


\section{REFERENCES}

1. Paly IA. Linear programming, study guide, 2008; 560.

2. Orlov AI. Theory of decision making. Tutorial. - M .: Publishing house "Mart", 2004; 656.

3. Yakubov M. S., Shikhnazarova G. A. The choice of priority principles of the dietetics of a balanced diet, Advanced Information Technologies March 2017, Samara, 570-572.

4. Yakubov MS, Shikhnazarova GA. System analysis of the processes of the effect of the differentiated nutritional and dietary regimen on the prenatal development of the child. Medical and Environmental Information Technologies.2016, Kursk 282-288.

5. Shikhnazarova GA, Masharipov BB. The mathematical model of pregnant women in food, Scientific progress May 2017 Ufa ISSN 2542-0984 61-63.

6. Yakubov M.S., Shikhnazarova G.A. Improving the health care system based on information. 2017; 3: 74-76.

7. Yakubov M.S., Shikhnazarova G.A. Algorithm for prenatal diagnosis of fetal development, Scientific progress February. 2017; (2):38-40. 